\title{
Burn unit: colonization of burn wounds and local environment
}

\author{
Yanık ünitesi: Yanık yarası ve çevresinde kolonizasyon
}

\author{
Touria ESSAYAGH, ${ }^{1}$ Alban ZOHOUN, ${ }^{2}$ Khalid TOURABI, ${ }^{3}$ Mohamed Amine ENNOUHI, ${ }^{3}$ \\ Abdellatif BOUMAAROUF, ${ }^{3}$ Hsain IHRAI, ${ }^{3}$ Sakina ELHAMZAOUI ${ }^{2}$
}

\section{BACKGROUND}

We present the results of a comparative prospective study of the resistance profile of strains isolated from pathological material of patients hospitalized in the burn unit of the military hospital in Rabat and from their environment over a period of one and a half years (July 2009-February 2011).

\section{METHODS}

The study concerned 125 pathological products from patients (40 men, 20 women; mean age $38 \pm 14.8$ years; range 2 to 80 years) hospitalized with burns. This allowed the isolation of 86 non-redundant bacterial strains during the first period and 50 during the second.

\section{RESULTS}

The dominant species were Acinetobacter baumannii (15.6\%), followed by Pseudomonas aeruginosa (13.8\%) and Staphylococcus aureus (11\%). During the second period, we noted the abundance of $A$. baumannii (15.5\%), followed by $P$. aeruginosa $(11.3 \%)$ and Klebsiella pneumoniae $(8.5 \%)$. Of the 104 environmental samples of burn patients, 139 microorganisms were isolated. Coagulase-negative staphylococcus was the most abundant strain in the two study periods (69.2\% and 64.6\%).

\section{CONCLUSION}

All species showed an almost identical sensitivity to the various antibiotics tested.

Key Words: Antibiotic resistance; bacterial ecology; burn patient; burn unit.

\section{$\boldsymbol{A M} \boldsymbol{A C}$}

Rabat'daki askeri hastanenin yanık ünitesine yatırılan hastalardan ve bunların çevrelerinden 1,5 yıllık bir süre içinde (Temmuz 2009-Şubat 2011) elde edilen patolojik materyalden izole edilen suşların direnç profiline ait karşılaştırmalı bir prospektif çalışmanın sonuçları sunuldu.

\section{GEREÇ VE YÖNTEM}

Bu çalışmada, yanıkları nedeniyle hastaneye yatırılan has-

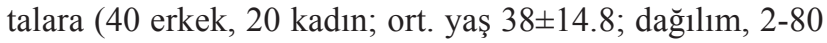
yaş) ait 125 patolojik ürünle çalışıldı. Birinci periyot süresinde 86 , ikinci periyot süresinde de 50 artıksız bakteriyel suş izole edildi.

\section{BULGULAR}

Baskın suşlar sırasıyla, Acinetobacter baumannii $(\% 15,6)$, Pseudomonas aeruginosa $(\% 13,8)$ ve Staphylococcus aureus $(\% 11)$ oldu. İkinci periyot süresinde $A$. baumannii $(\% 15,5)$, P. aeruginosa $(\% 11,3)$ ve Klebsiella pneumoniae $(\%$ 8,5) suşlarının çok olduğunu saptandı. Yanıklı hastalardan elde edilen 104 çevresel örnekten 139 mikroorganizma izole edildi. Koagülaz-negatif stafilokok, iki çalışma periyodunda da en fazla görülen suş oldu (\%69,2 ve $\% 64,6)$.

\section{SONUÇ}

Bütün suşlar, test edilen değişik antibiyotiklere karşı hemen hemen özdeş duyarlılık göstermiştir.

Anahtar Sözcükler: Antibiyotik direnci; bakteriyel ekoloji; yanık hastası; yanık ünitesi.

\footnotetext{
${ }^{1}$ Medicine College of Rabat, University Mohamed V Souissi, Rabat;

${ }^{1}$ Mohamed V Souissi Üniversitesi, Rabat Tıp Fakültesi, Rabat ${ }^{2}$ Mohamed V Askeri Eğitim Hastanesi, Mikrobiyoloji Bölümü, Rabat; ${ }^{3}$ Mohamed V Askeri Eğitim Hastanesi, Yanık Birimi, 
Intensive care units of hospitals include seriously ill patients who are extremely vulnerable to infections. Those units and their patients provide a niche for opportunistic organisms that are generally harmless to healthy people but are often very resistant to antibiotics and can cause epidemic spread among patients. ${ }^{[1]}$ Indeed, infections by those microorganisms are difficult to treat and may lead to increased morbidity and mortality in weakened burn patients, ${ }^{[2-5]}$ thereby increasing associated costs of care. The Burns Unit (BU) of the Military Hospital in Rabat is one of those intensive care units; it contains 14 beds with three in reanimation, two baths, two operating rooms, and toilets.

Our study aims were to identify the bacteria responsible for infections in immunodepressed patients and to determine their antibiotic sensitivity profile in order to reduce the risks related to infections and to better inform probabilistic antibiotic therapy.

\section{MATERIALS AND METHODS}

We divided our study into two periods: the first period of 10 months and the second for eight months, separated by a maintenance phase in the BU, primarily involving painting the walls. During this renovation period, the BU remained operational.

\section{Patients}

Sixty patients admitted to the BU in the Military Hospital in Rabat, Morocco during the period from 28 July 2009 till 1 February 2011 were included in this study. There were 20 women and 40 men. Their ages ranged from 2-80 years, with a mean of $38 \pm 14.8$ years. The causes of burn were exposure to flame $(n=53)$, electricity $(n=3)$ and nitric acid $(n=1)$, while the rest represented toxic epidermal necrolysis syndrome. These three patients did not present any mucosal complication like gastrointestinal bleeding or perforation. The total body surface area (TBSA) burned was divided as $\leq 15 \%$ or $>15 \%$, with an average of $30 \pm 12.73 \%$.

\section{Biological materials}

The microbial colonization of all wounds was studied from admission till the last surgical procedure. Upon admission, bacteriological samples were taken. The sampling procedure was carried out after cleaning each wound. Later, swabs were taken on occasions of surgical debridement or surgical excision and grafting. In each sampling procedure, the bandages were removed, the remnants of any topical antimicrobial agents were scraped away, and the wounds were swabbed before washing and applying the new topical antimicrobial agent. Sampling of environmental swabs from patients was done a few days after admission.

\section{Microbiology}

Isolation of microorganisms was primarily on blood agar plates, and identification was made based on morphological and biochemical characteristics. Antibiotic susceptibility was performed using the method of agar diffusion on Mueller-Hinton with use of antibiotic discs. The bacteria were classified as categorysensitive (S) or resistant (R) following the recommendations of the French Society for Microbiology.

\section{RESULTS}

The bacterial profile of microbial samples taken from the wounds of burn patients during the two study periods is shown in Table 1.

The first period of this study concerned 76 bacteriological samples as opposed to 49 during the second period: $35.2 \%$ corresponded to superficial pus, $35.2 \%$ to blood cultures, $10.4 \%$ to cytobacteriological urine studies, $12 \%$ to catheters, and $5.6 \%$ to "other". During the first part of the study, 86 bacteria were identified, predominantly as Acinetobacter baumannii (15.6\%), Pseudomonas aeruginosa (13.8\%) and Staphylococ-

Table 1. Organisms isolated from wounds of burn patients in the two periods (2009-2011)

\begin{tabular}{|c|c|c|}
\hline & $\begin{array}{l}\text { First } \\
\text { period } \\
\mathrm{n}(\%)\end{array}$ & $\begin{array}{c}\text { Second } \\
\text { period } \\
\mathrm{n}(\%)\end{array}$ \\
\hline \multicolumn{3}{|l|}{ Enterobacteriaceae } \\
\hline Citrobacter koseri & $1(0.9 \%)$ & - \\
\hline Comamonas testosterone & $1(0.9 \%)$ & $1(1.4 \%)$ \\
\hline Escherichia coli & $2(1.8 \%)$ & $1(1.4 \%)$ \\
\hline Enterobacter cloacae & $6(5.5 \%)$ & $5(7 \%)$ \\
\hline Serratia marcescens & $2(1.8 \%)$ & $1(1.4 \%)$ \\
\hline Klebsiella pneumoniae & $7(6.4 \%)$ & $6(8.5 \%)$ \\
\hline Morganella morganii & $1(0.9 \%)$ & $0(0 \%)$ \\
\hline Pantoea spp & $1(0.9 \%)$ & $0(0 \%)$ \\
\hline Proteus mirabilis & $6(5.5 \%)$ & $2(2.8 \%)$ \\
\hline Proteus vulgaris & $3(2.8 \%)$ & $2(2.8 \%)$ \\
\hline Providencia stuartii & $1(0.9 \%)$ & $0(0 \%)$ \\
\hline \multicolumn{3}{|l|}{ Nonfermenting Gram-negative bacilli } \\
\hline Stenotrophomonas maltophilia & $1(0.9 \%)$ & $0(0 \%)$ \\
\hline Ralstonia pickettii & $2(1.8 \%)$ & $0(0 \%)$ \\
\hline Pseudomonas aeruginosa & $15(13.8 \%)$ & $8(11.3 \%)$ \\
\hline Acinetobacter baumannii & $17(15.6 \%)$ & $11(15.5 \%)$ \\
\hline \multicolumn{3}{|l|}{ Cocci } \\
\hline Enterococcus faecalis & $3(2.8 \%)$ & $2(2.8 \%)$ \\
\hline Staphylococcus aureus & $12(11 \%)$ & $5(7 \%)$ \\
\hline Coagulase-negative staphylococcus & $2(1.8 \%)$ & $5(7 \%)$ \\
\hline Streptococcus spp & $3(2.8 \%)$ & $1(1.4 \%)$ \\
\hline \multicolumn{3}{|l|}{ Other } \\
\hline Candida albicans & $2(1.8 \%)$ & $1(1.4 \%)$ \\
\hline Candida non albicans & $2(1.8 \%)$ & $1(1.4 \%)$ \\
\hline Sterile & $19(17.4 \%)$ & $19(26.8 \%)$ \\
\hline Total & $109(100 \%)$ & $71(100 \%)$ \\
\hline
\end{tabular}


Table 2. Organisms isolated from the environment of burn patients during the two periods (20092011)

\begin{tabular}{lcc}
\hline & $\begin{array}{c}\text { First } \\
\text { period } \\
\mathrm{n}(\%)\end{array}$ & $\begin{array}{c}\text { Second } \\
\text { period } \\
\mathrm{n}(\%)\end{array}$ \\
\hline $\begin{array}{lcc}\text { Enterobacteriaceae } \\
\quad \text { Escherichia coli }\end{array}$ & $1(1.1 \%)$ & $0(0.0 \%)$ \\
Nonfermenting Gram-negative bacilli & & \\
$\quad$ Pseudomonas aeruginosa & $1(1.1 \%)$ & $3(6.3 \%)$ \\
Acinetobacter baumannii & $\mathrm{ND}$ & $1(2.1 \%)$ \\
Pasteurella haemolytica & $1(1.1 \%)$ & $0(0.0 \%)$ \\
Cocci & & \\
$\quad$ Staphylococcus aureus & $13(14.3 \%)$ & $8(16.7 \%)$ \\
$\quad$ Coagulase-negative staphylococcus & $63(69.2 \%)$ & $31(64.6 \%)$ \\
Fungi & $1(1.1 \%)$ & $0(0.0 \%)$ \\
$\quad \begin{array}{l}\text { Aspergillus niger } \\
\text { Aspergillus spp }\end{array}$ & $7(7.7 \%)$ & $5(10.4 \%)$ \\
Mucor spp & $4(4.4 \%)$ & $0(0.0 \%)$ \\
Total & $91(100 \%)$ & $48(100 \%)$ \\
\hline
\end{tabular}

cus aureus (11\%), whereas during the second period, 50 bacteria were isolated, with an abundance of $A$. baumannii (15.5\%), followed by $P$. aeruginosa $(11.3 \%)$ and Klebsiella pneumoniae (8.5\%).

The profile of microorganisms in the environment of burn patients during the study periods is shown in Table 2.

The first period of the study concerned 69 samples versus 35 in the second. $31.4 \%$ corresponded to surface samples, $25.7 \%$ to air samples, $20 \%$ to lower than the table surface, $11 \%$ to the bedside, and $5.5 \%$ each to the sheets and bathtubs.

Ninety-one microorganisms were isolated during the first period of the study, with 12 corresponding to fungi, in contrast to 48 microorganisms in the second period, with 5 corresponding to fungi. Coagulase-negative staphylococcus (CNS) and S. aureus strains were most abundant during the study period.

The study of the sensitivity profile to the antibiotics tested concerned the three most abundant species.
Staphylococci: We followed the resistance of $S$. aureus and CNS to fusidic acid (FA), erythromycin (E), penicillin (oxacillin [OXA]), aminoglycosides (tobramycin [TOB] and gentamicin [GN]), and glycopeptides (vancomycin [VA] and teicoplanin [TEC]). The results are summarized in Table 3. The $S$. aureus isolated during the study showed that resistance was around $40 \%$ for FA, E and OXA. Their sensitivity to glycopeptides is absolute. $23.5 \%$ of $\mathrm{S}$. aureus isolated were methicillin-resistant $S$. aureus (MRSA). CNS were relatively sensitive to the different antibiotics tested.

Nonfermenting Gram-negative bacilli: The percentage of resistance of $A$. baumannii and $P$. aeruginosa isolated during the different periods of the study is shown in Table 4. P. aeruginosa showed sensitivity to the different antibiotics tested.

K. pneumoniae showed sensitivity to amikacin (AN), colistin (CS), fosfomycin (FOS), carbapenems (imipenem [IMP]), and ticarcillin (TIC). However, sensitivity to netilmicin (NET), sulfamethoxazole trimethoprim (SXT), ciprofloxacin (CIP), and amoxicillin acid (AMC) was relatively low. $8.2 \%$ of Enterobacteriaceae identified corresponded to Enterobacteriaceae with extended-spectrum beta lactamase (ESBL).

Staphylococci: We followed the resistance of $S$. aureus and CNS to the same antibiotics for Staphylococci isolated from patients' wounds. The results are summarized in Table 5. CNS was sensitive to the different antibiotics tested, while $S$. aureus showed marked resistance to penicillins, GN, NIV, E, and TEC and sensitivity to VA. $23.8 \%$ were MRSA.

Nonfermenting Gram-negative bacilli: The three strains of $P$. aeruginosa isolated during the second period of the study showed $66.7 \%$ resistance to TIC and cephalosporin $3 \mathrm{G}$ (ceftazidime [CAZ]) and absolute sensitivity to IMP and amikacin (AK).

\section{DISCUSSION}

Prior and present knowledge of the bacterial profile of the BU and of the profile of bacterial sensitivity

Table 3. Antibiotic resistance profiles for Staphylococcus spp from wounds of burn patients in the two periods (2009-2011)

\begin{tabular}{|c|c|c|c|c|c|c|c|c|c|}
\hline & & $\begin{array}{c}\mathrm{AF} \\
\mathrm{n}(\%)\end{array}$ & $\begin{array}{c}\mathrm{E} \\
\mathrm{n}(\%)\end{array}$ & $\begin{array}{c}\mathrm{GN} \\
\mathrm{n}(\%)\end{array}$ & $\begin{array}{c}\mathrm{KA} \\
\mathrm{n}(\%)\end{array}$ & $\begin{array}{l}\text { OXA } \\
\text { n }(\%)\end{array}$ & $\begin{array}{l}\text { TEC } \\
\mathrm{n}(\%)\end{array}$ & $\begin{array}{l}\text { TOB } \\
\text { n }(\%)\end{array}$ & $\begin{array}{c}\mathrm{VA} \\
\mathrm{n}(\%)\end{array}$ \\
\hline First period & $\begin{array}{l}\text { Staphylococcus aureus } \\
(\mathrm{n}=12, \mathrm{CNS} \mathrm{n}=2)\end{array}$ & $\begin{array}{l}5(41.7 \%) \\
2(100 \%)\end{array}$ & $\begin{array}{c}5(41.7 \%) \\
1(50 \%)\end{array}$ & $\begin{array}{c}4(33.3 \%) \\
1(50 \%)\end{array}$ & $\begin{array}{l}1(8.3 \%) \\
1(50 \%)\end{array}$ & $\begin{array}{c}4(33.3 \%) \\
1(50 \%)\end{array}$ & $\begin{array}{l}0(0 \%) \\
0(0 \%)\end{array}$ & $\begin{array}{l}5(41.7 \%) \\
2(100 \%)\end{array}$ & $\begin{array}{l}0(0 \%) \\
0(0 \%)\end{array}$ \\
\hline Second period & $\begin{array}{l}\text { Staphylococcus aureus } \\
(n=5, \text { CNS } n=5)\end{array}$ & $\begin{array}{c}2(40 \%) \\
0(0 \%)\end{array}$ & $\begin{array}{c}2(40 \%) \\
0(0 \%)\end{array}$ & $\begin{array}{l}3(60 \%) \\
1(20 \%)\end{array}$ & $\begin{array}{l}2(40 \%) \\
1(20 \%)\end{array}$ & $\begin{array}{l}2(40 \%) \\
1(20 \%)\end{array}$ & $\begin{array}{c}\text { ND } \\
0(0 \%)\end{array}$ & $\begin{array}{l}3(60 \%) \\
1(20 \%)\end{array}$ & $\begin{array}{l}0(0 \%) \\
0(0 \%)\end{array}$ \\
\hline
\end{tabular}

AF: Fusidic acid; E: Erythromycin; GN: Gentamicin; KA: Kanamycin; TEC: Teicoplanin; OXA: Oxacillin 5 нg; TOB: Tobramycin; VA: Vancomycin; ND: Not determined. 
Table 4. Antibiotic resistance profiles for nonfermenting Gram-negative bacilli from wounds of burn patients in the two periods (2009-2011)

\begin{tabular}{llcccc}
\hline & & Amikacin & Ceftazidime & \multicolumn{2}{c}{ Imipenem } \\
& & $\mathrm{n}(\%)$ & $\mathrm{n}(\%)$ & $\mathrm{n}(\%)$ & $\mathrm{n}(\%)$ \\
\hline \multirow{2}{*}{ First period } & P. aeruginosa $(\mathrm{n}=15)$ & $4(12.5 \%)$ & $3(20 \%)$ & $4(26.7 \%)$ & $6(40 \%)$ \\
& A. baumannii $(\mathrm{n}=17)$ & $11(34.4 \%)$ & $14(43.8 \%)$ & $1(3.1 \%)$ & $14(43.8 \%)$ \\
Second period & P. aeruginosa $(\mathrm{n}=8)$ & $2(6.9 \%)$ & $3(10.3 \%)$ & $3(10.3 \%)$ & $7(24.1 \%)$ \\
& A. baumannii $(\mathrm{n}=11)$ & $6(20.7 \%)$ & $11(37.9 \%)$ & $8(27.6 \%)$ & $8(27.6 \%)$ \\
\hline
\end{tabular}

Table 5. Antibiotic resistance profiles for Staphylococcus spp from the environment of burn patients in the two periods (2009-2011)

\begin{tabular}{llcccccccc}
\hline & & $\mathrm{AF}$ & $\mathrm{E}$ & $\mathrm{GN}$ & $\mathrm{KA}$ & $\mathrm{OXA}$ & $\mathrm{TEC}$ & $\mathrm{TOB}$ & $\mathrm{VA}$ \\
$\mathrm{n}$ & & $\mathrm{n}(\%)$ & $\mathrm{n}(\%)$ & $\mathrm{n}(\%)$ & $\mathrm{n}(\%)$ & $\mathrm{n}(\%)$ & $\mathrm{n}(\%)$ & $\mathrm{n}(\%)$ & $\mathrm{n}(\%)$ \\
\hline First period & CNS=63 & $12(19.0 \%)$ & $6(9.5 \%)$ & $18(28.6 \%)$ & $7(11.1 \%)$ & $8(12.7 \%)$ & $7(11.1 \%)$ & $2(3.2 \%)$ & $0(0 \%)$ \\
& S. aureus $(\mathrm{n}=13)$ & $5(38.5 \%)$ & $5(38.5 \%)$ & $4(30.8 \%)$ & $4(30.8 \%)$ & $3(23.1 \%)$ & $4(30.8 \%)$ & $2(15.4 \%)$ & $0(0 \%)$ \\
Second period & CNS=31 & $2(6.5 \%)$ & $6(19.4 \%)$ & $7(22.6 \%)$ & $1(3.2 \%)$ & $3(9.7 \%)$ & $4(12.9 \%)$ & $1(0 \%)$ & $0(0 \%)$ \\
& S. aureus $(\mathrm{n}=8)$ & $5(62.5 \%)$ & $5(62.5 \%)$ & $4(50.0 \%)$ & $4(50.0 \%)$ & $3(37.5 \%)$ & $4(50.0 \%)$ & $2(0 \%)$ & $0(0 \%)$ \\
\hline
\end{tabular}

AF: Fusidic acid; E: Erythromycin; GN: Gentamicin; KA: Kanamycin; TEC: Teicoplanin; OXA: Oxacillin 5 pg; TOB: Tobramycin; VA: Vancomycin.

to antibiotics by isolates is necessary for the successful treatment of severe infections. We undertook this study to identify the bacteria responsible for infections in immunodepressed patients and to determine their antibiotic sensitivity profile. During the course of the study, we analyzed 129 bacteriological samples from wounds of patients in the BU, and 136 non-redundant bacterial strains were identified. Thirty-eight samples were sterile. One hundred and four environmental samples were obtained, and 122 bacterial strains were identified.

P. aeruginosa was the second most abundant species in both study periods, and its sensitivity to the antibiotics tested was shown. This was corroborated by other authors like Revathi, Panit, Lari, and Kaushik. [6-9]

This high rate of $P$. aeruginosa could be explained by the exposure of patients to balneotherapy. ${ }^{[10,11]}$ Tredget ${ }^{[11]}$ mentions in his study that the bacilli pyocyaneus easily survive in the aquatic environment due to their low nutrient requirements exogenously; hence, the advantage of dressings in bed. Cremer ${ }^{[12]}$ found an abundance of $P$. aeruginosa in the early practice of hydrotherapy.

A. baumannii was the most dominant strain in our study, and it showed resistance to the various antibiotics tested. Those strains can be found in various sites in the patient's environment, including bed curtains, furniture and hospital equipment. ${ }^{[13]}$ This bacteria can be spread through the air over short distances in water droplets and in the scales of the skin of patients who are colonized, ${ }^{[14]}$ but the most common mode of transmission is from the hands of hospital staff. Patients who are colonized or infected by A. baumannii can carry this strain at different body sites for periods of days to weeks. ${ }^{[15]}$ A. baumannii can survive in dry conditions. ${ }^{[16]}$

The various strains of Staphylococcus spp isolated have shown almost the same sensitivity phenotype, with the presence of $23 \%$ of MRSA. The majority of our identified strains showed almost the same pattern of antibiotic resistance, allowing us to deduce that there are clones that are circulating in our BU that pass from one room to another via the medical staff and paramedics, and via hospital patients who have been transferred to other rooms. These factors may also explain the presence of almost the same rate of MRSA isolated from wounds of patients as from their environment $( \pm 23 \%)$. Currently, the emergence of strains of S. aureus with reduced susceptibility to vancomycin (VA) is a major problem, especially after the first Japanese report described the isolation of a strain of S. aureus resistant to VA. In our study, among the 38 strains of S. aureus studied, no strain was resistant to glycopeptides accounted for by VA. ${ }^{[17,18]}$ The same result was not found in a Tunisian University Hospital. ${ }^{[19]}$ The renovation that was undertaken in the BU involved primarily painting the walls, and resulted in the elimination of Aspergillus niger and Mucor sp.

This should be complemented by other more stringent measures and tips to ensure a reduction of bacterial infections of patients' wounds. 
Faced with the risk of multi-resistant bacteria broadcasts within the unit or the hospital, the establishment of a program to combat the spread of these bacteria and compliance with standards of hospital hygiene are paramount.

\section{REFERENCES}

1. Dijkshoorn L, Nemec A, Seifert H. An increasing threat in hospitals: multidrug-resistant Acinetobacter baumannii. Nat Rev Microbiol 2007;5:939-51.

2. Vindenes H, Bjerknes R. Microbial colonization of large wounds. Burns 1995;21:575-9.

3. Le Floch R, Arnould JF, Pilorget A. Effect of systematic empiric treatment with imipenem on the bacterial ecology in a burns unit. Burns 2005;31:866-9.

4. Signorini M, Grappolini S, Magliano E, Donati L. Updated evaluation of the activity of antibiotics in a burn centre. Burns 1992;18:500-3.

5. Ramakrishnan MK, Sankar J, Venkatraman J, Ramesh J. Infections in burn patients--experience in a tertiary care hospital. Burns 2006;32:594-6.

6. Revathi G, Puri J, Jain BK. Bacteriology of burns. Burns 1998;24:347-9.

7. Pandit DV, Gore MA, Saileshwar N, Deodhar LP. Laboratory data from the surveillance of a burns ward for the detection of hospital infection. Burns 1993;19:52-5.

8. Lari AR, Alaghehbandan R. Nosocomial infections in an Iranian burn care center. Burns 2000;26:737-40.

9. Kaushik R, Kumar S, Sharma R, Lal P. Bacteriology of burn wounds--the first three years in a new burn unit at the Medical College Chandigarh. Burns 2001;27:595-7.

10. Sharma BR, Harish D, Singh VP, Bangar S. Septicemia as a cause of death in burns: an autopsy study. Burns 2006;32:5459.

11. Tredget EE, Shankowsky HA, Joffe AM, Inkson TI, Volpel $\mathrm{K}$, Paranchych W, et al. Epidemiology of infections with
Pseudomonas aeruginosa in burn patients: the role of hydrotherapy. Clin Infect Dis 1992;15:941-9.

12. Cremer R, Ainaud P, Le Bever H, Fabre M, Carsin H. Nosocomial infections in a burns unit. Results of a prospective study over a year. [Article in French] Ann Fr Anesth Reanim 1996;15:599-607.

13. van den Broek PJ, Arends J, Bernards AT, De Brauwer E, Mascini EM, van der Reijden TJ, et al. Epidemiology of multiple Acinetobacter outbreaks in The Netherlands during the period 1999-2001. Clin Microbiol Infect 2006;12:837-43.

14. Bernards AT, Frénay HM, Lim BT, Hendriks WD, Dijkshoorn L, van Boven CP. Methicillin-resistant Staphylococcus aureus and Acinetobacter baumannii: an unexpected difference in epidemiologic behavior. Am J Infect Control 1998;26:544-51.

15. Dijkshoorn L, Van Vianen W, Degener JE, Michel MF. Typing of Acinetobacter calcoaceticus strains isolated from hospital patients by cell envelope protein profiles. Epidemiol Infect 1987;99:659-67.

16. Jawad A, Seifert H, Snelling AM, Heritage J, Hawkey PM. Survival of Acinetobacter baumannii on dry surfaces: comparison of outbreak and sporadic isolates. J Clin Microbiol 1998;36:1938-41.

17. Gil M, Otth L, Wilson M, Arce E, Zaror A, Lizama V. Determination of the in vitro activity of 2 glycopeptides (vancomycin and teicoplanin) against methicillin-resistant Staphylococcus aureus of intrahospital origin. [Article in Spanish] Rev Med Chil 2000;128:111-2.

18. Rybak MJ, Akins RL. Emergence of methicillin-resistant Staphylococcus aureus with intermediate glycopeptide resistance: clinical significance and treatment options. Drugs 2001;61:1-7.

19. Garnier F, Mariani-Kurkdjian P, Nordmann P, Ferroni A, VuThien H, Philippe JC, et al. Sensibilité aux antibiotiques des souches de staphylocoques et d'entérocoques isolées en pédiatrie. Médecine et Maladies Infectieuses 2002;32:432-8. 